\title{
Optimizing Zoom Application for Virtual Research Presentation: Awareness and Experience of Researchers in Nigerian Library School.
}

\author{
Halimah Odunayo, AMUDA ${ }^{*^{*}}$, Yusuf Ayodeji, AJANI ${ }^{2}$ \\ ${ }^{1}$ Library and Information Science Unit, Department of Science Education, Al-Hikmah University, \\ Ilorin \\ ${ }^{2}$ Postgraduate Student,Department of Library and Information Studies,The University of Ilorin, \\ Nigeria
}

\begin{abstract}
COVID-19 pandemic has forced many tertiary institutions in Nigeria, especially private institutions whose source of income solely depend on the school fees paid by their students to move all in-person courses to a remote learning and research format. As a result, many faculties in Nigerian Library schools had opted for transition of their teaching and research activities to virtual using zoom application. This study explored researchers' awareness and experience on the use of zoom application for virtual research presentation. The study was limited to lecturers in Nigerian library schools. A mixed approach was used to gather information from ninety- eight respondents. Total enumeration sampling technique was adopted with a questionnaire administered through online platforms. Findings of this study established that the use of zoom application for online presentation is now prominent among researchers in Nigerian Library schools. The result also revealed that using zoom for virtual research presentation is very interesting and highly satisfactory. The study concluded that zoom is suitable for virtual research presentation when compare to physical presentation. Thus, it was recommended that; technical difficulties associated with the use of zoom could be tackled through the provision of written instruction before the presentation.
\end{abstract}

\section{Introduction}

Information and Communication Technology (ICT) has become an essential driver of everyday life and economic activity in the present world. Arkorful, Barfi, and Aboagye [1] buttressed this assertion by stating that the new dimension in the use of ICT has brought remarkable changes in knowledge delivery and academic system worldwide is progressively becoming massive users of ICT tools. These tools offer lots of new opportunities when it comes to academic research output. An array of ICT tools are readily available for any

*Corresponding author: amudahalimah@gmail.com 
researcher who is willing to undertake virtual research presentation. These tools include but not limited to; Todoist that enables researchers to manage all of their projects and access them from any platform they own such as their desktops or laptops. Endnote is another ICT tool that helps researchers to search for information in an online database as well as full texts based on abstracts, it could also be used by researchers to manage and auto-complete their references. Skype is a video conferencing tool designed for easy communication. It allows researchers to communicate their research findings via screen sharing, instant messaging, file sharing, as well as informal video or audio calls right from their $\mathrm{PC} /$ phone.

Using Skype, researcher can send quick messages to their respondents as well as their audience. Although skype has been identified as a powerful ICT tool designed to take communications in research to the next level Seitz [2], nevertheless, Yan [3] has argued that the enhancements to the Zoom platform on free and paid tiers give it a slight edge over skype. Zoom is a web-based service and it allows groups of professionals to create a semi-public profile within a bounded system; articulate a list of other users with whom they share a connection; and view and traverse their list of connections and those made by others within the system Dhar, Bose \& Khan [4]. Zoom application as a collaboration platform offers highdefinition (HD) Video and Audio features, and it has a digital whiteboard that can be used to break out rooms in a meeting and to join meetings easily, accessibility functions and the ability to record meetings which could have up to 100 participants and can last for 24 hours. With zoom application, people can join meetings using a computer rather than using a telephone. In view of the aforementioned advantages of Zoom, it is not a gain saying that the platform is suitable for online research presentation. However, a number of article in the last few days had questioned the suitability of the platform as a viable video conferencing platform, owing to its perceived privacy / security issues. The reality is that Zoom is not the only platform that has issues, a thorough check of the media revealed similar questions that have been raised about many other video conferencing platforms such as Skype, WhatsApp and Todoist to mention a few. The fact is that every emerging technology comes with its own issues.

Zoom was founded by Eric Yuan in 2011 and was launched in January 2013. The app. has been in existence and used for online teaching and research for many years but this amazing resource gained its popularity in 2020 during the scourge of Corona virus pandemic across the globe. The COVID-19 pandemic has forced many tertiary institutions, especially private institutions whose source of income solely depend on the school fees paid by their students to move all in-person courses to a remote or online learning and research format. All universities, library schools inclusive in Nigeria were prevented by Nigeria Centre for Disease Control (NCDC), Nigeria University Commission and COVID-19 task force from having physical academic activities since the beginning of the scourge of the pandemic spanning from March- September, 2020. As a result, many faculties in Nigerian Library schools opted for transition of their teaching and research activities to virtual using web conferencing tools like Zoom. With particular reference to Al-Hikmah University, a library school in Nigeria, all her graduating students resulted to online presentation of their seminar and research project using Zoom application due to the imposition of lockdown on all Nigerian citizens as a result of the scourge of Corona Virus. Knowing fully well that most private Universities in Nigeria get their Internally Generated Income (IGR) solely from the tuition fees paid by their students, the university was left with no other option than to transit to online learning and research activities. Despite the challenges of Covid-19, the graduating students were able to successfully present their seminar and research project remotely using Zoom application. It was a huge achievement for both the students and the institution itself. On the part of the students, they were able to graduate in record time while the institution was able to sustain its financial obligations. In addition to this, there was a significant increase in the students' enrollment in the subsequent academic session. 


\subsection{Statement of the Problem}

A number of studies had examined the use of information and communication technologies (ICT) tools for conducting research e.g. Mercieca; Lo Iacono; Horrell, Stephens \& Breheny $[5,24,21]$ but only a few focused on the use of Zoom application for virtual presentation in the context of Nigerian Library School. Moreover, it has been observed that most public universities in Nigeria are aware of Zoom application but they are not aware of its potentials as a powerful tool for virtual research presentation which could in-turn lead to under recognition and underutilization of the tool. Additionally, the number of research on the use of Zoom application as a tool for virtual research presentation is still very low, hence, further research into researchers' awareness and experiences of using zoom for virtual research presentation is necessary.

\subsection{Objectives of the study}

This study explored researchers' awareness and experience on the use of zoom application for virtual research presentation by;

1. examining the acceptability and feasibility of using zoom application for virtual research presentation in library schools;

2. investigating perception of researchers on the use of zoom application for virtual research presentation in library schools

3. investigating the impacts of using zoom application for research presentation; and

4. identify the challenges associated with the usage of zoom application for research presentation in library schools.

\section{Literature Review}

There is a limited literature on the use of Zoom Application for Virtual research presentation: Thus, scholarly articles on other conferencing tools would also be considered relevant to the study.

\subsection{Evolution of Zoom Application}

Zoom video conferencing platform was founded in 2011 by Eric Yuan who was a former Corporate Vice President of Engineering Cisco Systems and its collaboration business unit. Zoom app. was launched in January 2013 and towards the end of May, 2013, the app. had recorded one million subscribers across the globe. Initially, Zoom app. was designed in such a way that it could host conferences having up to 15 video participants at a stretch which later increased to 25 in January 2013 and to version 2.5 which could host 100 participants in October 2013 . By June 2014, Zoom could boast of 10 million users. By February 2015, the population of users of zoom application moved from 10 million to 40 million, with 65,000 organizations subscribers. Between 2011 and 2015, the company had hosted a total of 1 billion meetings.

In September 2015, Zoom company integrated Zoom video conferencing with Salesforce's customer relationship management platform, allowing salespeople to initiate such conferences with their sales leads without leaving the application. Between 2015 and mid-2016, Zoom Video Communications announced native support for Skype for Business and integration with Slack. In May 2017, Zoom announced a partnership with Polycom that integrated Zoom's video meetings into Polycom's conferencing systems, enabling features such as multiple screen and device meetings, HD and wireless screen sharing, and calendar 
integration with Microsoft Outlook, Google Calendar, and iCal. In September 2017, Zoom hosted Zoomtopia 2017, Zoom's first annual user conference. During theCOVID-19 pandemic, Zoom application saw a major increase in usage forremote work,distance education and online social relations. Thousands of educational institutions switched to online classes using Zoom applicaton. The company offered its services for free to schools in many countries. By February 2020, Zoom had gained 2.22 million users than it amassed in the entirety of 2019.

On March 2020, the Zoom application was downloaded 2.13 million times. Daily average users rose from about 10 million in December 2019 to more than 300 million daily meeting participants in April 2020. This led to an increase in the company's stock price in early 2020, despite a general stock market downturn. In June 2020, the company hired its first chief diversity officer, Damien Hooper-Campbell. Zoom has become nearly synonymous with corporate presentation, office meetings and socializing as people around the world have adapted to life at home amid the corona-virus outbreak. As the corona-virus pandemic forced millions of people to stay home over the past month, Zoom application suddenly became the video meeting service of choices and the daily meeting participants on the platform surged from 10 million to 200 million in December, 2020.

\subsection{Using Videoconferencing Applications for Online Presentation}

Virtual research presentation has been considered by many researchers as the best alternative for face-to-face presentation especially during COVID-19 pandemic which have impeded physical academic activities in tertiary institutions. More researchers have become familiar with various Video conferencing platforms that could be used to transmit their research findings. It is also assumed that increasing number of researchers have seen the need to improve their competence in the use of advanced technological tools which could consequently make their participation in online presentation easier. Before a researcher could use any of the videoconferencing platforms effectively, some certain skills are required. Number one requirement is that the prospective researcher must know how to connect to the internet using digital devices such as computer, tablets, and smartphones and so on. Another important requirement is that a secluded place is required to prevent unnecessary interruptions from their neighborhoods.

It will also do a whole lots of good if the presentation is not a lengthy one so as to avert unforeseen technical issues. As mentioned in the background of this study, it is necessary for researchers to acquaint themselves with the functionalities of the platform if they don't want to run into trouble during their presentations. Extant literature has revealed the most commonly and easy-to-use Video conferencing platforms that researchers can take advantage of; these include;Skype, a video conferencing tool that provides free audio and video calls. It is often of used by researchers. Lo Iacono, Symonds and Brown [24] opined that Skype is given preference by researcher over other videoconferencing tools because they believe it works best via the downloadable rather than the browser based version. With Skype both one-to-one calls and one-to-many, are possible. According to Lobe, Morgan and Hoffman [6], One of the features of Skype is the Audio/video recordings which makes audio/video recordings easy. One-click access feature of skype allow participants and the host to have opportunity to be signed into their previously acquired free of charge Skype accounts. Privacy features on other hand allow participants who are added to the call by a host or who are provided a link from a host to participate. Skype uses AES 256 bit encryption but is not HIPAA compliant.

Go To Meeting is available at www.gotomeeting.com. It provides a HD video that enables a researcher to set up a personal meeting room that can be used several times using 
the same invitation link. It enables researchers to share their screens with their audience. The platform has a Business plan version that allows the user to translate and transcribe their contents. 150 participants can participate in a session. Webex is another web conferencing tool. It is available at (www.webex.com). It can also be used for online presentation, According to $[6,15,18]$. Hosts are granted advanced administrative meeting controls such as encryption, chatoptions, recordings, and so on. Webex has recently lifted the time limits in their Free plan, which allows up to 100 participants per meeting. Audio/video recording is not available in the Free plan, thus researchers has to look for their owns screen capture solutions. One-click access feature does not require participants to have a Webex account before they could join the session but they need to download the software before their presentation.

Zoom, a videoconferencing platform, has already been used extensively for research purposes [7,17,26]. According to Lobe, Morgan and Hoffman [6], the platforms support realtime audio and full-motion video. The free Basic plan offers many useful settings that are user-friendly and intuitive. A participant can use the downloadable version of Zoom or merely sign in into a web-based version of it. Zoom enables audio/video recordings and control is limited to the host of the meeting, who can decide to share it with other participants. Utilization of Zoom application for virtual research presentation has gained popularity amongst researcher in the field of Library and Information Science across the globe [8]. Perhaps, owing to the awareness of academics about the potentials inherent in the use of Zoom app, more researchers are beginning to recognize the effectiveness of the tool in delivering virtual research presentation [9,14]. Some authors such as Singh, Abdullah, Moneyam, Ismail, Tek, and Singh [21] have reported that some researchers are skeptical about using the tool for their research presentation despite the fact that they are aware that the application is a useful tool for virtual research presentation. Puncreobutr[10] in his effort to allay the fear of these researchers cautioned that a researcher who is willing to make his or her research presentation online using zoom application ought to have familiarized him or herself with the functionalities of the tool before the final presentation because it could be kind of daunting if it has never been tried before.

\subsection{ZOOM as a Tool for Online Research Presentation}

Advanced technologies are now leveraged upon in academic domains [20]. In a survey conducted by Lata and Sonkar in 2020 [11], the authors suggested that researchers should think outside the box and adopt a more convenient way to communicate their research findings to their audience. This phenomenon has forced researchers in the field of library and information science to think and re-think and explore the use of zoom application for their research presentations. This is evident in the number of researchers that are turning to the use of zoom application for virtual research presentation. A number of studies (e.g. [12]) have reported that using zoom application, it is possible for researchers to stay involved quicker, easier and more fun with their audience during their presentations compare to face-to-face presentation. It also allows for easy, visible and audible connection of researcher with audience during presentation. In addition to this, the zoom application has necessitated alternative ways for researchers to share professional idea and enhance research productivity, and make collaboration more agile through virtual research presentation.

It has also been reported in literature that the application is used for other academic related purposes such as online class-rooms, distance learning and scholarly presentations. Supporting this, Romadhoni, Kiristiastuti, Nurlaela, Sutiadiningsih, Astuti, Pangesthi, [27] stressed that Zoom application is an indispensable tool for academic institutions because the app. seems to be the only solution to the problems of many of the institutions in this current 
era when the world is witnessing an economic downturn orchestrated by the outburst of the Covid-19 pandemic. To substantiate Romadhoni's view, Cerezo, Ramirez, O'Shaughnessy, Sanchez, Mattis, and Ross [16] stated that Zoom application is becoming increasingly popular as all ages of Researchers and professionals are now active users. The author further explained that many researchers spend time online to solve and share all possible academic possible problems due to the advantages and the nature of zoom application, which include: allowing people to communicate and build community online; facilitating syndication by sharing and reusing; and capitalising the knowledge of others and helping people learn easily.

Archibald, Ambagtsheer, Casey and Lawless [7] examined the use of information and communication technology tools that are used for conducting research and their findings revealed that zoom is a better tool for collection of qualitative data in research as compared to phone calls and face-to-face method of collecting same data. Similarly, a study conducted by Ramsook and Thomas [25] revealed that participants of the survey declared their preference for Zoom app. over Skype by reporting that there were deficiencies in the app, as many features such as creating and managing break-out rooms which could optimize learning and research do not come with the app.

\subsection{Impacts of Zoom Application for Virtual Research Presentation}

The impacts of modern ICT are increasing rapid in the modern world. It has become part and parcel of education system, especially in the education process. The use of new innovative ICT has been deeply rooted in the success of academics and the new trend is the exposure to virtual activities. Over the past few months, academics and institutes of higher learning have diversified their systems of research presentation to online presentation using video conferencing tool such as Zoom. Most library schools in Nigeria has hugely invested in this ICT resource in order to provide supports for researchers and students. Amid the COVID-19 pandemic and the need for social distancing, zoom application has significantly reshaped how research presentations are made by researchers.

A recent study by Sayem, Taylor, Mcclanachan and Mumtahina[13] found that due to improvements in technology and convenience in research activities, many researchers have chosen virtual mode of research presentation over face-to-face because it is a reliable tool that provides good quality audio and video conferencing. It is very easy to use and researchers do not have to undergo any training before using the platform. Other benefits that can be derived by researchers through the use of Zoom platform as highlighted by Archibald, Ambagtsheer, Casey and Lawless [7] include but not limited to; improved Internet access and increased use of electronic devices worldwide; convenience and cost-effectiveness of online platform compared to face-to face interaction, particularly when the research work is to be presented before the audiences over a large geographical spread; and the understanding that online methods can replicate, complement, and possibly improve upon traditional methods. Another key advantage of Zoom is its ability to securely record and store sessions without recourse to third-party software. This feature is particularly important in research where the protection of highly sensitive data is required.

\subsection{Challenges Associated with the use of Zoom Application for Virtual Research Presentation}

Despite the acceptability of Zoom as a tool for research presentations, some authors have raised some concerns about the tool. Among these authors are Putri, Purwanto, Pramono, Asbari, Wijayanti and Hyun[22] who argued that personal or individual factors such as behavior and unwillingness to adapt to change could pose a challenge in the use of Zoom for 
online research presentation. Most users are also constrained by various other factors in their quest for the effective use of the application. Some of these constraints are indicated in a study carried out by Putri, Purwanto, Pramono, Asbari, Wijayanti, \& Hyun [19]. This includes; not being familiar with the application, low skills, lack of needed facilities and interest, limited accessibility and network connection, limited technical support and lack of researcher's competency.

Other concerns associated with the use of zoom as reported by McMaster Research Ethics Board (2020) include the following: possibility of having uninvited guests as part of a meeting without the knowledge of meeting hosts; recordings made by zoom can be stored on a publicly accessibly cloud without the knowledge of meeting hosts; Non encryption of information on Zoom server. Despite these challenges, the fact still remains that using zoom for virtual research presentation has a lot of benefits in terms of usability and feasibility over physical presentation [23].

\section{Methodology}

\subsection{Design}

The study adopted a survey design methodology. A survey is commonly used in LIS/information system research to collect self-report data from study participants. A survey may focus on information about individuals, or it might aim to collect the opinions of the survey takers. A survey design was considered appropriate in this study because it gives room for the researcher to cover a substantial percentage of respondents (lecturers/researchers) in the universities that were covered in the study and to enable the generalization of the outcomes from the study.

\subsection{Population and Sample}

The population for the study comprised of researchers/lecturers from Library schools in the Federal Universities in the six geo-political zones of Nigeria. One Federal university each was selected to represent each of the six geo-political zones of Nigeria, the library schools in each of these universities were chosen. Cross River; (University of Calabar Library School), Enugu (University of Nigeria Library School), Oyo (University of Ibadan Library School), Kaduna (Ahmadu Bello University Library School), Kwara (University of Ilorin library School), and Maiduguri (Federal University Maiduguri Library School). This makes a total of six library schools that took part in the study. All lecturers of the selected library schools totaling ninety-eight (98) were covered in the study. Sample was drawn by applying total enumeration where all the respondents in the study population constituted the sample size.

\subsection{Instruments}

A questionnaire and interview were developed by the researchers that featured items on the five objectives of the study was developed. The questionnaire comprised of two major sections. Sections, A and B. Section A, requires the demographic information of the respondents, while section B featured the items. Section B was further divided into FOUR parts. Each part focused on the objectives of the study.

\subsection{Procedure of Administration}


An online survey was developed, reviewed by experts and scholars in the field of LIS, and piloted prior to implementation with a sample of the target audience. Pre-survey e-mail notes, invites and survey confirmation were sent to approximately 98 researchers in the six selected library schools. The survey was available for four weeks on the internet for the respondents to fill and return their respective responses. At the end of the four weeks, a total of 82 copies of the questionnaire were properly filled and returned. A face-to-face administration of the questionnaire and interview were not possible due to the second wave of Covid-19 where observation of all Covid-19 protocols especially social distancing was forcefully enforced.

\subsection{Data Analysis}

Both quantitative and qualitative data were collected. The qualitative data collected was analysed thematically while the quantitative data collected was analysed using percentage and frequency count, and the results were presented in Tables.

\section{Results}

\section{Table 1: Population and Response Rate}

S/N Federal University States Zones Population $\begin{aligned} & \begin{array}{l}\text { Response } \\ \text { Rate }\end{array} \\ & \text { nat }\end{aligned}$

\begin{tabular}{|c|c|c|c|c|c|}
\hline & $\begin{array}{l}\text { University of } \\
\text { Calabar }\end{array}$ & $\begin{array}{l}\text { Cross- } \\
\text { River }\end{array}$ & South-South & 14 & 13 \\
\hline 2. & $\begin{array}{l}\text { University of } \\
\text { Nigeria }\end{array}$ & $\begin{array}{l}\text { Enugu } \\
\text { State }\end{array}$ & South-East & 14 & 14 \\
\hline 3. & University of Ibadan & Oyо & South-West & 18 & 18 \\
\hline 4. & $\begin{array}{l}\text { Ahmadu Bello } \\
\text { University }\end{array}$ & Kaduna & North-West & 18 & 12 \\
\hline 5. & University of Ilorin & Kwara & $\begin{array}{l}\text { North- } \\
\text { Central }\end{array}$ & 16 & 13 \\
\hline 6. & $\begin{array}{l}\text { University of } \\
\text { Maiduguri }\end{array}$ & Bornu & North-East & 18 & 12 \\
\hline & Total & 6 & 6 & 98 & 82 \\
\hline
\end{tabular}

Source: Field Survey (2020)

\subsection{Acceptability and feasibility of using of zoom application for virtual research presentation}

The objective was to investigate the Acceptability and feasibility of using of zoom application for virtual research presentation. To achieve the objective, respondents were asked to indicate their level of agreement and disagreement. The result is presented in Table 2.

Table 2: Acceptability and Feasibility of Using of Zoom Application for Virtual Research Presentation 
International Conference of Information Communication Technologies enhanced Social Sciences and Humanities 2021 - ICTeSSH 2021

\begin{tabular}{|c|c|c|c|c|}
\hline $\mathbf{S} / \mathbf{N}$ & $\begin{array}{l}\text { Acceptability and feasibility on } \\
\text { the use of zoom application }\end{array}$ & Agreed & Not Sure & Disagreed \\
\hline 1. & $\begin{array}{l}\text { Zoom application has really been } \\
\text { helpful in the conduct of Virtual } \\
\text { research presentation }\end{array}$ & $78(95.1 \%)$ & $4(4.8 \%)$ & $0(0 \%)$ \\
\hline 2. & $\begin{array}{l}\text { Zoom application encourage other } \\
\text { professional colleagues to become } \\
\text { vast in the use of ICT }\end{array}$ & $47(57.3 \%)$ & $5(6.0 \%)$ & $30(36.6 \%)$ \\
\hline 3. & $\begin{array}{l}\text { Most researchers prefer using } \\
\text { zoom application for virtual } \\
\text { research presentation } \\
\text { physical presentation }\end{array}$ & $80(97.6 \%)$ & $2(2.4 \%)$ & $0(0 \%)$ \\
\hline 4. & $\begin{array}{l}\text { Zoom application substantiate the } \\
\text { modern level of academic system. }\end{array}$ & $80(97.6 \%)$ & $0(0 \%)$ & $2(2.4 \%)$ \\
\hline 5 . & $\begin{array}{l}\text { Zoom application replaces } \\
\text { physical presences with virtual } \\
\text { presence }\end{array}$ & $78(95.1 \%)$ & $1(1.2 \%)$ & $3(3.7 \%)$ \\
\hline 6. & $\begin{array}{l}\text { Most professional use zoom } \\
\text { application to share academic } \\
\text { knowledge and experience }\end{array}$ & $77(93.9 \%)$ & $5(6.1 \%)$ & $0(0 \%)$ \\
\hline 7. & $\begin{array}{l}\text { Apart from research presentation, } \\
\text { most researchers use zoom } \\
\text { application for training and } \\
\text { development }\end{array}$ & $66(80.5 \%)$ & $12(14.7 \%)$ & $4(4.9 \%)$ \\
\hline 8 . & $\begin{array}{l}\text { Zoom application has become part } \\
\text { and parcel of education system }\end{array}$ & $71(86.6 \%)$ & $9(10.9 \%)$ & $2(2.4 \%)$ \\
\hline 9. & $\begin{array}{l}\text { Using zoom application for } \\
\text { virtual research presentation is } \\
\text { very convenient }\end{array}$ & $52(63.4 \%)$ & $12(14.7 \%)$ & $18(21.9 \%)$ \\
\hline
\end{tabular}

\section{Source: Field Survey (2020)}

From the result in the Table 2, it is evident that the acceptability and the feasibility of using zoom for virtual research presentation is really high among researchers in the Nigerian library school with the response rate of $(97.6 \%)$. The result reveals that most of the respondents indicated that zoom application has really been helpful in the conduct of research presentation, the result also indicates that zoom application substantiate the modern level of academic system and also replaces physical presence with virtual presence. More importantly, the findings from the study reveal that most researchers use zoom application to share academic knowledge and experience. This result implies that the researchers in library school are very much aware of the presence and importance of zoom application for virtual research presentation.

\subsection{Perception of using of zoom application for virtual research presentation}

The objective was to investigate the researcher's perception of using of zoom application for virtual research presentation. To achieve the objective, respondents were asked to indicate their level of agreement and disagreement. The result is presented in Table 3.

Table 3: Perception of Using of Zoom Application for Virtual Research Presentation 
International Conference of Information Communication Technologies enhanced Social Sciences and Humanities 2021 - ICTeSSH 2021

\begin{tabular}{|c|c|c|c|c|}
\hline $\mathrm{S} / \mathrm{N}$ & $\begin{array}{l}\text { Perception on the use of zoom } \\
\text { application }\end{array}$ & Agreed & Not Sure & Disagreed \\
\hline 1. & $\begin{array}{l}\text { It is easy for me to learn how to use } \\
\text { zoom application for conduct of } \\
\text { virtual research presentation }\end{array}$ & $52(63.4 \%)$ & $16(19.5 \%)$ & $14(17.1 \%)$ \\
\hline 2. & $\begin{array}{l}\text { I feel comfortable when using Zoom } \\
\text { application to collaborate with other } \\
\text { professional colleagues }\end{array}$ & $53(64.6 \%)$ & $20(24.4 \%)$ & $9(10.9 \%)$ \\
\hline 3. & $\begin{array}{l}\text { It is very interesting when using } \\
\text { zoom application to help other } \\
\text { researchers in the conduct of virtual } \\
\text { research presentation }\end{array}$ & $53(64.6 \%)$ & $19(23.2 \%)$ & $10(12.1 \%)$ \\
\hline 4. & $\begin{array}{l}\text { I enjoyed virtual research } \\
\text { presentation over physical research } \\
\text { presentation }\end{array}$ & $41(50 \%)$ & $15(18.3)$ & $26(31.7 \%)$ \\
\hline 5. & $\begin{array}{l}\text { Interacting through zoom } \\
\text { application substantiate the modern } \\
\text { level of academic system. }\end{array}$ & $52(63.4 \%)$ & $16(19.5 \%)$ & $14(17.1 \%)$ \\
\hline 6. & $\begin{array}{l}\text { Using zoom application for virtual } \\
\text { research presentation was really a } \\
\text { pleasant experience }\end{array}$ & $41(50 \%)$ & $3(3.6 \%)$ & $38(46.3 \%)$ \\
\hline 7. & $\begin{array}{l}\text { using zoom application to share } \\
\text { knowledge was a good experience }\end{array}$ & $53(64.6 \%)$ & $20(24.3 \%)$ & $9(10.9)$ \\
\hline 8. & $\begin{array}{l}\text { Using zoom application improved } \\
\text { my ICT skills }\end{array}$ & $72(87.8 \%)$ & $3(3.6 \%)$ & $7(8.5 \%)$ \\
\hline 9. & $\begin{array}{l}\text { Using zoom application improves } \\
\text { my virtual research presentation } \\
\text { performance }\end{array}$ & $52(63.4 \%)$ & $17(20.7 \%)$ & $12(14.6 \%)$ \\
\hline 10. & $\begin{array}{l}\text { Using zoom application for virtual } \\
\text { research presentation is very } \\
\text { convenient }\end{array}$ & $80(97.6 \%)$ & $2(2.4 \%)$ & $0(0 \%)$ \\
\hline
\end{tabular}

\section{Source: Field Survey (2020)}

The results in Table 3 reveal the perception of researchers in the use of zoom application for virtual research presentation in Nigerian library school and it indicates that most of the researchers with the response rate of $(97.6 \%)$ indicates that using zoom application for virtual research presentation is very convenient; convenience in the sense that they do not need to leave the comfort of their house before research presentation can be done. (64\%) feel comfortable with using zoom application to collaborate with other professional colleagues, $(87 \%)$ of the respondents indicates that using zoom application improve their ICT skills, $(64 \%)$ of the respondents indicates that using zoom application to share knowledge was a good experience and (63\%) of the respondents agreed that using zoom application improves their virtual research presentation performance while $(50 \%)$ of the respondents disagreed they enjoyed virtual research presentation over physical research presentation and $(50 \%)$ of the respondents also disagreed that using zoom application for virtual research presentation was really a pleasant experience. This result however, implies that there is a mixed feelings about the usage of zoom application by researchers in Nigerian library school because some of them were not comfortable with the usage of zoom application for virtual research presentation. 
International Conference of Information Communication Technologies enhanced Social Sciences and Humanities 2021 - ICTeSSH 2021

\subsection{Impact of using of zoom application for virtual research presentation}

The objective was to investigate the impact of using of zoom application for virtual research presentation. To achieve the objective, respondents were asked to indicate their level of agreement and disagreement. The result is presented in Table 4.

Table 4: Impact of Using of Zoom Application for Virtual Research Presentation

\begin{tabular}{|c|c|c|c|c|}
\hline $\begin{array}{l}\mathrm{S} / \\
\mathrm{N}\end{array}$ & ITEMS & Agreed & Not Sure & Disagreed \\
\hline 1. & $\begin{array}{l}\text { Using zoom application for Virtual } \\
\text { research presentation is cost- } \\
\text { effectiveness }\end{array}$ & $78(95.1 \%)$ & $4(4.8 \%)$ & $0(0 \%)$ \\
\hline 2. & $\begin{array}{l}\text { Using zoom application for virtual } \\
\text { research presentation make } \\
\text { knowledge sharing become so easy }\end{array}$ & $80(97.5 \%)$ & $0(0 \%)$ & $2(2.4 \%)$ \\
\hline 3. & $\begin{array}{l}\text { Using zoom application for virtual } \\
\text { research presentation stimulates } \\
\text { researchers interest to teach }\end{array}$ & $56(68.3 \%)$ & $\begin{array}{l}14 \\
(17.0 \%)\end{array}$ & $12(14.6 \%)$ \\
\hline 4. & $\begin{array}{l}\text { Using zoom application for virtual } \\
\text { research presentation ensure better } \\
\text { retention of knowledge of the } \\
\text { researchers }\end{array}$ & $48(58.5 \%)$ & $4(4.8 \%)$ & $30(36.5 \%)$ \\
\hline 5. & $\begin{array}{l}\text { I consider using zoom application for } \\
\text { virtual research presentation as a } \\
\text { wastage of time }\end{array}$ & $52(63.4 \%)$ & $\begin{array}{l}17 \\
(20.7 \%)\end{array}$ & $12(14.6 \%)$ \\
\hline 6. & $\begin{array}{l}\text { Using zoom application for virtual } \\
\text { research presentation makes learning } \\
\text { to become more viable }\end{array}$ & $80(97.5 \%)$ & $2(2.4 \%)$ & $0(0 \%)$ \\
\hline 7. & $\begin{array}{l}\text { Using zoom application for virtual } \\
\text { research presentation is very } \\
\text { expensive }\end{array}$ & $62(75.6 \%)$ & $6(7.3 \%)$ & $14(17.0 \%)$ \\
\hline 8. & $\begin{array}{l}\text { Using zoom application for virtual } \\
\text { research presentation improves } \\
\text { relevance of research }\end{array}$ & $38(46.3 \%)$ & $\begin{array}{l}26 \\
(31.7 \%)\end{array}$ & $18(21.9 \%)$ \\
\hline 9. & $\begin{array}{l}\text { Using zoom application for virtual } \\
\text { research presentation reduces rich- } \\
\text { poor digital divide }\end{array}$ & $80(97.5 \%)$ & $2(2.4 \%)$ & 0() \\
\hline 10. & $\begin{array}{l}\text { Using zoom application for virtual } \\
\text { research presentation give voice to the } \\
\text { voiceless }\end{array}$ & $36(43.1 \%)$ & $4(4.8 \%)$ & $42(51.2 \%)$ \\
\hline
\end{tabular}


International Conference of Information Communication Technologies enhanced Social Sciences and Humanities 2021 - ICTeSSH 2021

\begin{tabular}{|l|l|l|l|l|}
\hline 11. & $\begin{array}{l}\text { Using zoom application for virtual } \\
\text { research presentation improves social } \\
\text { acceptability }\end{array}$ & $78(95.1 \%)$ & $4(4.8 \%)$ & $0(0 \%)$ \\
\hline 12. & $\begin{array}{l}\text { Using zoom application for virtual } \\
\text { research presentation enhances digital } \\
\text { capacity building }\end{array}$ & $82(100 \%)$ & $0(0 \%)$ & $0(0 \%)$ \\
\hline
\end{tabular}

Source: Field Survey (2020)

The results in Table 4 reveal the impact of the usage of zoom application for virtual research presentation by researchers in Nigerian library school. The findings from the study indicates that most of the researchers with the response rate of $(95.1 \%)$ agreed that using zoom application for virtual research presentation is cost-effective, (97.5\%) of the respondents agreed that using zoom application for virtual research presentation makes knowledge sharing become so easy, (97.5\%) of the respondents indicates that using zoom application for virtual research presentation makes learning to become more viable and (97.5\%) of the agreed using zoom application for virtual research presentation reduces rich-poor digital divide. Also $(95.1 \%)$ of the respondent agreed that using zoom application for virtual research presentation improves social acceptability while $(75.6 \%)$ of the respondents agreed that using zoom application for virtual research presentation is very expensive and (56\%) of the respondents also disagreed that Using zoom application for virtual research presentation give voice to the voiceless. This result however, implies that zoom platform enhances social acceptability, improves digital capacity and cost-effective compared to face-to face presentation, particularly when the research work is to be presented outside the geographical location of the presenter.

\subsection{Challenges associated with the usage of zoom application for virtual research presentation}

The objective was to investigate the challenges associated with the usage of zoom application for virtual research presentation. To achieve the objectives, respondents were asked to explain the challenges they are facing in the use of zoom for virtual research presentation. The challenges listed were summarized into seven major categories and were analysed based on the Friedman test. The results were shown in the table 5.

Table 5: Challenges Associated with the Usage of Zoom Application for Virtual Research Presentation
S/N ITEMS
Frequency Percent

\begin{tabular}{llll}
\hline 1. & $\begin{array}{l}\text { Technical know-how difficulties/Low ICT } \\
\text { knowledge }\end{array}$ & 14 & 17.0 \\
2. & Network issue & 14 & 17.0 \\
3. & Cost of data subscription & 16 & 19.5 \\
4. & Technophobia & 12 & 14.6 \\
5. & Limited power supply & 15 & 18.2 \\
6. & Lack of training & 11 & 13.4 \\
\hline
\end{tabular}


International Conference of Information Communication Technologies enhanced Social Sciences and Humanities 2021 - ICTeSSH 2021

\section{Total}

82

100

\section{Source: Field Survey (2020)}

Table 5 reveals the challenges associated to the use of zoom application for virtual research presentation in Nigerian library schools. The results reveal that so many challenges are noticeable. They are cost of data subscription, technical difficulties, network issue, low ICT knowledge and technical know -how difficulties, lack of training on the use of the zoom application for research presentation.

\subsection{What challenges do you envisage in using zoom application for virtual research presentation?}

A respondent has this to say:

"To use the zoom application for virtual research presentation, LIS schools in Nigeria will have to go extra miles. The reason is that our problems are numerous. This begins with given orientation training to researchers. The attitude and manner which most of these university staff show towards any online participation is very poor, most of them prefer physical presentations to virtual research presentation. As a result of this, I think adapting to online environment is one of their major problems "I will like to call it technophobia"

Another respondent explained that:

"What I perceived as one of the major challenge associated with the use of zoom application for virtual research presentation is that ........the cost of data subscription is overwhelming" coupled with the fact that the university internet service is disappointing. Many at times, for lecturers to use zoom platform for virtual research presentation it costs them huge amount of money to subscribe for data as a result of the fact the university internet service is so poor and many of the lecturers complain about using their personal money to subscribe for a better internet service.

One respondent succinctly emphasised that:

"I can see low level of ICT knowledge and limited power supply as major challenges associated with the use zoom application. Currently, we have been hearing it and reading it in the literature how many African researchers in library schools are lagging behind in the use of modern ICT due to the fact that faculties do not provide ICT training for the lecturers. Having said that, power outages have also being a major challenge facing the efficient use of zoom application for virtual research presentation.... Many a times, while using zoom application on my laptop, the electricity will suddenly get interrupted and at times, the energy back-up on most laptop may not sustain longer while using zoom application on it. Unfortunately, none of our library schools is ready to provide an alternative energy back-up such as electricity generating set or solar inverter. Since no alternative energy back-ups are provided, how can we sustain the use of zoom application for virtual research presentation in library schools in Nigeria?"

This result implies that there are significant challenges associated with usage of zoom application for virtual research presentation and this is evident from the justifications of the respondents as well as it implies in the Table 5.

\section{Discussion}


Consistent with previous studies into video conferencing tools (e.g., Archibald, Ambagtsheer, Casey and Lawless [7], this study found that most researchers in Nigerian Library schools are very much aware of the presence and importance of zoom application for virtual research presentation. The study has established the fact that participants recognize Zoom app. as an effective and promising tool for online research presentation, however, the platform was not given preference over the face-face mode. In this study, it is possible that researchers' willingness to still hold on to the face-to-face online presentation could reflect either their low level of digital skills in the use of videoconferencing platforms or they were previously unfamiliar with the platform. The finding of this study that online research presentation using zoom is convenient and cost-effective is in agreement of the finding of Lobe et. al.[6]. The finding also suggests that the participants found Zoom application interesting, friendly and very satisfactory. The participants also admitted that zoom platform enhances their social acceptability and digital capacity compared to face-to face presentation. This finding is in consonance with the study of Lo Iaconoet.al.[24] who also got similar response in their study. Although, challenges such as cost of data subscription, technical difficulties, network issue, low ICT knowledge and technical know-how difficulties, lack of training on the use of the zoom application for research presentation were identified by the participants but the major constraint to the use of Zoom for virtual research presentation is cost of data subscription. This finding is in line with the experience of the researchers during an online presentation of research project by some graduating students in a library school that is not within the coverage of this study. Some of the final year students could not graduate because of their inability to present their research virtually using zoom because they could not afford to pay for data subscription. This same constraint is also the major reason some researchers in Nigerian higher institutions do not participate in webinar. Additionally, this study affirms that the benefits of using Zoom for online research presentation has significantly outweighed the challenges militating against the use of the platform.

\section{Conclusion}

This study has considered the awareness and experience of researchers in optimising zoom application for virtual research presentation in Nigerian library school. The paper drew 98 researchers in the Nigerian Library School who were administered questionnaire through online forums/platforms. The result revealed that majority of the respondents indicates that they are very much aware of the presence and importance of zoom application for virtual research presentation. Majority of the respondents also indicates that their experiences of using Zoom application for virtual research presentation as being very interesting and highly satisfactory, they also note that using zoom application is very convenient and Costeffectiveness compared to face-to face presentation, particularly when the research work is to be presented outside the geographical location of the presenter. Challenges identified in the study were technical difficulties, network issue, cost of data subscription, low ICT knowledge and lack of training.

\subsection{Recommendations}

Based on the findings of the study, the following are recommended. Library schools in Nigeria should consider training as a major strategy to accommodate the teaching of the use of zoom application for virtual research presentation.

Based on the findings of the study, it is recommended that technical difficulties associated with the use of Zoom for virtual research could be tackled or reduced through the provision of written instruction before the presentation session. The study concluded that Zoom is a 
more suitable platform for virtual research presentation when compared to face-to face or physical research presentation.

The government through the ministry of education should make more funds available for the subscription of a stable internet service for the optimum use of zoom application for virtual research presentation. It is also important that stakeholders/policy makers should consider the sustainability of internet services in library schools in order to encourage the maximum output of research presentations.

\subsection{Limitations and Suggestions for further research}

This study has examined the awareness and experience of Nigerian library schools in optimising zoom application for virtual research presentation. Since there is no perfect research, some limitations are noticeable. The study focused on only six library schools in the six geo-political zones in Nigeria out of many other library schools in the country. Extending the study to other library schools in the remaining parts of the country will bring worthwhile and valuable results generalizable to the entire library schools in Nigeria.

Secondly, data in the study was collected using a self-reported open and closed-ended instrument, and the sample size was limited to LIS researchers from six library schools where the instrument was administered. Therefore, future studies should consider embarking on a pure qualitative study of the optimization of zoom application for virtual research presentation in Nigeria.

Future research should examine other possible areas and gaps identified in the study.

\section{References}

1 Arkorful, V., Barfi, K. A., \& Aboagye, I. K. (2021). Integration of information and communication technology in teaching: Initial perspectives of senior high school teachers in Ghana. Education and Information Technologies, 1-17.

2 Seitz, S. (2016). Pixilated partnerships, overcoming obstacles in qua-litative interviews via Skype: A research note.QualitativeResearch,16, 229-235

3 Yan, J. (2020). Zoom Vs. Skype. Available online @ https://www.dgicommunications.com/zoom-vs-skype/ , Retrieved on $5^{\text {th }}$, April, 2020 ,

4 Dhar, S., Bose, I., \& Khan, M. N. (2021). Digital Social Networks From a Social Capital Perspective. In Encyclopedia of Information Science and Technology, Fifth Edition (pp. 1106-1117). IGI Global.

5 Mercieca, B. M. (2021). Sustaining online teacher networks. InSustaining Communities of Practice with Early Career Teachers (pp. 65-97). Springer, Singapore

6 Lobe, B., Morgan, D., \& Hoffman, K. A. (2020). Qualitative Data Collection in an Era of Social

7 Archibald, M. M., Ambagtsheer, R. C., Casey, M. G., \& Lawless, M. (2019). Using zoom videoconferencing for qualitative data collection: perceptions and experiences of researchers and participants. International Journal of Qualitative Methods, 18, 1609406919874596.

8 Amin, F. M., \&Sundari, H. (2020). EFL students' preferences on digital platforms during emergency remote teaching: Video Conference, LMS, or Messenger Application?.Studies in English Language and Education, 7(2), 362-378.

9 Rui, J., \&Stefanone, M. A. (2013). Strategic self-presentation online: A crosscultural study. Computers in Human Behavior, 29(1), 110-118. 
10 Puncreobutr, V. (2016). Education 4.0: New challenge of learning. St. Theresa Journal of Humanities and Social Sciences, 2(2).

11 Lata, N., \&Sonkar, S. K. (2020). Impact of ICT on learning activities of user by academic library services: A Literature Review. Library Philosophy and Practice, $1-18$.

12 Ryn, A. S., \&Sandaran, S. C. (2020). Teachers' practices and perceptions of the use of ict in elt classrooms in the pre-covid 19 pandemic era and suggestions for the'new normal'. LSP International Journal, 7(1).

13 Sayem, A. S. M., Taylor, B., Mcclanachan, M., \&Mumtahina, U. (2017). Effective use of zoom technology and instructional videos to improve engagement and success of distance students in engineering. In 28th annual conference of the Australasian association for engineering education (AAEE 2017) (p. 926). Australasian Association for Engineering Education.

14 Bisht, R. K., Jasola, S., \& Bisht, I. P. (2020). Acceptability and challenges of online higher education in the era of COVID-19: a study of students' perspective. Asian Education and Development Studies.

15 Dash, S., Samadder, S., Srivastava, A., Meena, R., \& Ranjan, P. (2021). Review of Online Teaching Platforms in the Current Period of COVID-19 Pandemic. Indian Journal of Surgery, 1-6.

16 Cerezo, A., Ramirez, A., O’Shaughnessy, T., Sanchez, A., Mattis, S., \& Ross, A. (2021). Understanding the power of social media during COVID-19: Forming social norms for drinking among sexual minority gender expansive college women. Journal of Homosexuality, 1-17.

17 Daniels,N.,Gillen,P.,Casson,K.,\&Wilson,I.(2019).STEER:Factors to consider when designing online focus groups usingaudiovisual technology in health research. https://journals.sagepub.com/doi/full/10.1177/1609406919885786।

18 Dhika, H., Destiawati, F., Surajiyo, S., \& Jaya, M. (2021). Distance Learning During the Pandemic Period of COVID-19 with Zoom and Webex Comparison.

19 Putri, R. S., Purwanto, A., Pramono, R., Asbari, M., Wijayanti, L. M., \& Hyun, C. C. (2020). Impact of the COVID-19 pandemic on online home learning: An explorative study of primary schools in Indonesia. International Journal of Advanced Science and Technology, 29(5), 4809-4818.

20 Spector, J. M. (2015). Foundations of educational technology: Integrative approaches and interdisciplinary perspectives. Routledge.

21 Horrell, B., Stephens, C., \&Breheny, M. (2015). Online research using Skype with informal caregivers: Opportunities and challenges. Qualitative Research in Psychology, 12, 258-271.

22 Singh, C. K. S., Singh, T. S. M., Abdullah, N. Y., Moneyam, S., Ismail, M. R., Tek, O. E., ... \& Singh, J. K. S. (2020). rethinking english language teaching through telegram, whatsapp, google classroom and zoom. Sys Rev Pharm, 11(11), 45-54.

23 Pandey, D., Ogunmola, G. A., Enbeyle, W., Abdullahi, M., Pandey, B. K., \&Pramanik, S. (2021). COVID-19: A Framework for effective delivering of online classes during lockdown. Human Arenas, 1-15

24 Lo Iacono, V., Symonds, P., \& Brown, D. H. (2016). Skype as a tool for qualitative research interviews. Sociological Research Online, 21(2), 103-117.

25 Ramsook, L., \& Thomas, M. (2019). Perspectives of Prospective teachers on Zoom as a transformative teaching methodology. International Journal for Innovation Education and Research, 7(11), 946-957. 
26 Matthews, K., Baird, M., \& Duchesne, G. (2018).Using online meet-ing software to facilitate geographically dispersed focus groups forhealth workforce research. https://journals.sagepub.com/doi/abs/10.1177/1049732318782167

27 Romadhoni, I. F., Kiristiastuti, D., Nurlaela, L., Sutiadiningsih, A., Astuti, N., Pangesthi, L. T., ... \& Bahar, A. (2020, November). Diverse Forms of V-learning Students' Acceptability During the Pandemic Covid-19. In International Joint Conference on Science and Engineering (IJCSE 2020) (pp. 80-85). Atlantis Press. 